\title{
Effects of cutting and nitrogen deposition on biodiversity in Cantabrian heathlands
}

\author{
Calvo, L. ${ }^{1 *}$; Alonso, I. ${ }^{2}$; Marcos, E. ${ }^{1,3}$ \& De Luis, E. ${ }^{1,4}$ \\ ${ }^{1}$ Área de Ecología, Fac. Ciencias Biológicas y Ambientales, Universidad de León, 24071 León, Spain; ${ }^{2}$ English Nature, \\ Northminster House, Peterborough PE1 1UA, UK; E-mail isabel.alonso@english-nature.org.uk; \\ ${ }^{3}$ E-mail degemp@unileon.es; ${ }^{4}$ E-maildegelc@unileon.es; \\ *Corresponding author; Fax +34 987291501; E-mail deglcg@unileon.es
}

\begin{abstract}
Questions: Does the diversity of heathland vegetation change when subjected to experimental disturbances such as cutting and nitrogen fertilization? Do changes in the vegetation structure negatively affect the regeneration of the dominant species $\mathrm{Cal}$ luna vulgaris? Is cutting an alternative method of conserving the diversity and maintaining the structure of heathlands in the Cantabrian Mountains?

Location: Calluna vulgaris heathlands on the southern slopes of the Cantabrian Mountain range, NW Spain.

Methods: A total of 60 plots were treated with different combinations of cutting and twice the estimated atmospheric deposition of nitrogen $\left(56 \mathrm{~kg}-\mathrm{N} \cdot \mathrm{ha}^{-1} \cdot \mathrm{yr}^{-1}\right)$. The changes in the cover values of the species present were monitored over a five year study period. The cover values were used to calculate abundance and species richness.

Results: Fertilizing with nitrogen allows biodiversity to increase over time. However, the greatest biodiversity is associated with the cutting plus fertilization treatment, since cutting allows gaps to be opened that are easily colonized by pioneer annual species, while fertilization mainly favours an increase in the mean number of perennial herbs (graminoids and forbs). Increased perennial herb richness also corresponds to a rise in their cover values. The recovery of the dominant woody species in these communities, Calluna vulgaris, is not impeded by the increase in perennial herbs species' cover values.

Conclusions: In the Calluna vulgaris heathlands studied, cutting plus fertilization allowed an increase in biodiversity over time. No displacement of the dominant woody species, Calluna vulgaris, is observed due to the presence of the perennial herbs. Cutting patches of heathland is recommended as a mechanism for maintaining high vegetation diversity, when grazing is not possible.
\end{abstract}

Keywords: Atmospheric deposition; Calluna vulgaris; Life form.

Nomenclature: Tutin et al. (1964-1980).

\section{Introduction}

One of the characteristic plant communities in the Cantabrian mountains (NW Spain) is heathland dominated by Calluna vulgaris. These communities represent the most southerly examples of this type of heathland in western Europe. Heathlands were recognized as an important habitat by the European Union Habitats Directive in 1992 (Anon. 1992). This has contributed to making these habitats the subject of many research studies aimed at conservation. Similarly, because of their conservational importance, many heathlands have become nature reserves in recent years, as has occurred in the heathlands of the Cordillera Cantábrica.

Traditionally, these areas in NW Spain were used for grazing sheep, goats, cattle and horses in transhumance pastoral systems. As part of the management, burning and cutting were regularly used to maintain pastures. These activities were similar to those which contributed to maintaining and expanding heathlands in other parts of western Europe (Webb 1998). However, traditional management has nearly disappeared in most countries as well as in the Cantabrian mountains due to changes in agricultural practices and for socio-economic reasons. As a result of these changes, patches characterized by $\mathrm{Cal}$ luna vulgaris and other dwarf ericaceous species, such as Erica tetralix, are scarce in the Cantabrian mountains (Calvo et al. 2002, 2005). Furthermore, the lack of management has resulted in the remaining areas of heathland being in a mature to degenerate state (sensu Watt 1955), which may affect the regenerative potential and biodiversity when subjected to disturbances (Mohamed \& Gimingham 1970; Berdowski \& Siepel 1988).

Studies performed over the past 50 years have shown a progressive loss of these habitats, with large-scale replacement of the shrub vegetation by more competitive grasses (Pitcairn \& Fowler 1995; Marrs 1993; Britton et al. 2001), scrub and/or woodlands (Rose et al. 2000). Several factors might be involved in the direction of these changes: lack of cutting or burning management, changes 
in grazing regime and the deposition of atmospheric pollutants, including increased deposition of atmospheric nitrogen (Carroll et al. 1999). In many of these areas there are attempts to stimulate certain traditional management activities such as grazing or burning, because of their importance in maintaining biodiversity (Hanson \& Fogelfors 2000).

In the Cantabrian mountain range, besides the mentioned changes in the traditional management, there has been an increase in the atmospheric deposition of nitrogen (Rivero Fernández et al. 1996). Increases in the long-term rate of nitrogen supply are likely to lead to changes in the vegetation, mainly in the biodiversity and structure of the community, including the loss of more sensitive species (Press et al. 1986; Pitcairn \& Fowler 1995) and a shift in the structure of the vegetation towards more competitive species (Heil \& Diemont 1983; Bobbink 1991).

The aim of this study is to analyse the effect of cutting the woody species and of simulated atmospheric nitrogen deposition on the vegetation biodiversity and structure of the heathlands in the Cantabrian mountain range. We also intend to test the hypothesis that changes in vegetation structure as a result of management actions could negatively affect the regeneration of the dominant species (Calluna vulgaris). Finally, we will attempt to define an adequate management strategy for these heathlands that maintains high diversity and the characteristic structure of these communities.

\section{Material and Methods}

The study site is located on the León (south) side of the Cantabrian mountain range (NW Spain). Three areas, ca. $25 \mathrm{~km}$ apart, were selected: San Isidro (1600 $\mathrm{m}$ a.s.1., $\left.43^{\circ} 03^{\prime} \mathrm{N}, 1^{\circ} 40^{\prime} \mathrm{W}\right)$, Tarna ( $1625 \mathrm{~m}$ a.s.1., $43^{\circ} 04^{\prime}$ $\mathrm{N}, 1^{\circ} 33^{\prime} \mathrm{W}$ ) and Vegarada (1585 $\mathrm{m}$ a.s.1., $43^{\circ} 02^{\prime} \mathrm{N}, 1^{\circ} 48^{\prime}$ $\mathrm{W})$. The climate of the three areas is Eurosiberian (Rivas Martínez et al. 1987). The mean annual temperature is $5.5^{\circ} \mathrm{C}$ and the mean annual rainfall is $1319 \mathrm{~mm}$ in all areas. The climatic conditions are characterized by a warm season with no (or less than two months) aridity (months in which temperatures $\left({ }^{\circ} \mathrm{C}\right.$ ) are higher than twice the value of rainfall in $\mathrm{mm}$ ). The study areas represent a range of different soil characteristics, mainly in terms of soil moisture (Tarna is the wettest and San Isidro the driest) and nutrient content in terms of organic matter, nitrogen and phosphorous. Soils in all areas are podsols, although the underlying rocks differ.

In April 1998, an area of ca. 1-2 ha containing a significant proportion of both Calluna and Erica was randomly selected in each study area. There are no records of when they were last burned or cut, but all the stands were at a mature stage (sensu Watt 1955) between 25 and 40 years old.

Twenty experimental plots $(1 \mathrm{~m} \times 1 \mathrm{~m})$ were selected and marked in each study area in a block design distribution pattern, where plots of the same block were physically close together. The percentage cover of each vascular plant species present was estimated visually. The data were used to determine abundance by life form: woody species, perennial herbs, perennial forbs, perennial graminoids, annual herbs, annual forbs, annual graminoids and total richness (species number) and richness by life form.

The 20 plots were assigned, in a randomized block design, to one of the five replicates of each of the four following treatments to alter the vegetation structure and soil nutrient levels:

1. No cutting, No fertilization (control)

2. No cutting, Annual fertilization

3. Removal of Calluna and Erica No fertilization

4. Removal of Calluna and Erica, Annual fertilization

o
F
C
CF

The cutting treatment for Calluna vulgaris and Erica tetralix was done by hand to ground level. This treatment was applied only once at the start of the experiment and the clipped material was removed from the plots.

The fertilizer, consisting of granules of ammonium nitrate, was spread by hand each year from 1998 to 2003 once within two weeks after snow melting at the sites (late April to early May). The fertilization level (56 kgN.ha ${ }^{-1} \cdot \mathrm{yr}^{-1}$ ) was chosen to be equivalent to twice the estimated current background pollution levels in this area (Rivero Fernández et al. 1996).

After the treatments, changes in the percentage cover of each vascular species present were monitored annually for five years and visually estimated to determine abundance and richness as described above.

\section{Data analysis}

Cover values of each vascular species were used to determine the cover of the following life forms: woody, perennial herbs: perennial graminoids, perennial forbs and annual herbs: annual forbs and annual graminoids.

Data from cover percentage and richness values of the life forms were analysed by means of factorial ANOVA. For statistical analyses, data expressed as percentage cover were arcsine-square root transformed prior to analysis and submitted to three factor repeated measures ANOVA, factor one: time as the repeated measures, second factor: experimental treatments (cutting, fertilization, cutting plus fertilization), and third factor: study areas (San Isidro, Vegarada and Tarna). To indicate the differences between the original and treated situations, the original data were included. If a repeated measures test 
(General Linear Model) detected significant interactions between time and treatment for each dependent variable, one way ANOVA tests were carried out for each sample date separately. Post-hoc Tukey tests were carried out to determine the significance of the differences. Statistical tests were carried out using the Statistical Program for the Social Sciences 11.5 (SPSS 1989-2002).

A Principal Component Analysis (PCA) was carried out in order to distinguish the effects of experimental treatments in the composition of the vegetation and their structural parameters. Variables were standardized previous to statistical treatment of data. The variables used in the analysis were percentage cover values and richness for the different life forms. PCA analysis was carried out using the programme STATISTICA 6.0 by Statsoft 1984-2001.

The significance of linear correlations between perennial herbaceous cover and perennial graminoids cover with Calluna cover was tested by calculating Pearson correlation coefficients.

\section{Results}

\section{Effects of fertilization}

Richness

The impact of fertilization was studied by comparing the (O) control plots with the (F) fertilized plots (Fig. 1). After fertilization a significant increase was observed in the total richness values in two of the zones studied: Vegarada $(F=8.05 ; P<0.05)$ from the first year postfertilization and in San Isidro $(F=10.87, P<0.05)$ from the fourth year. This increase in total richness was due to the contribution of perennial herb species (Fig 1), with significant differences in Vegarada $(F=9.32 ; P<0.05)$ and San Isidro $(F=6.93, P<0.05)$ between fertilized $(\mathrm{F})$ and control $(\mathrm{O})$ plots. No significant effects of fertilization on the richness of the annual herb or woody species were apparent in any of the study areas.

By the end of the study period (five years), only the fertilized plots $(F)$ showed any significant increases relative to the original situation $(F=7.55 ; P<0.01)$ in terms of total richness in the three areas, mainly due to the perennial herb contribution (Fig. 1) in Vegarada
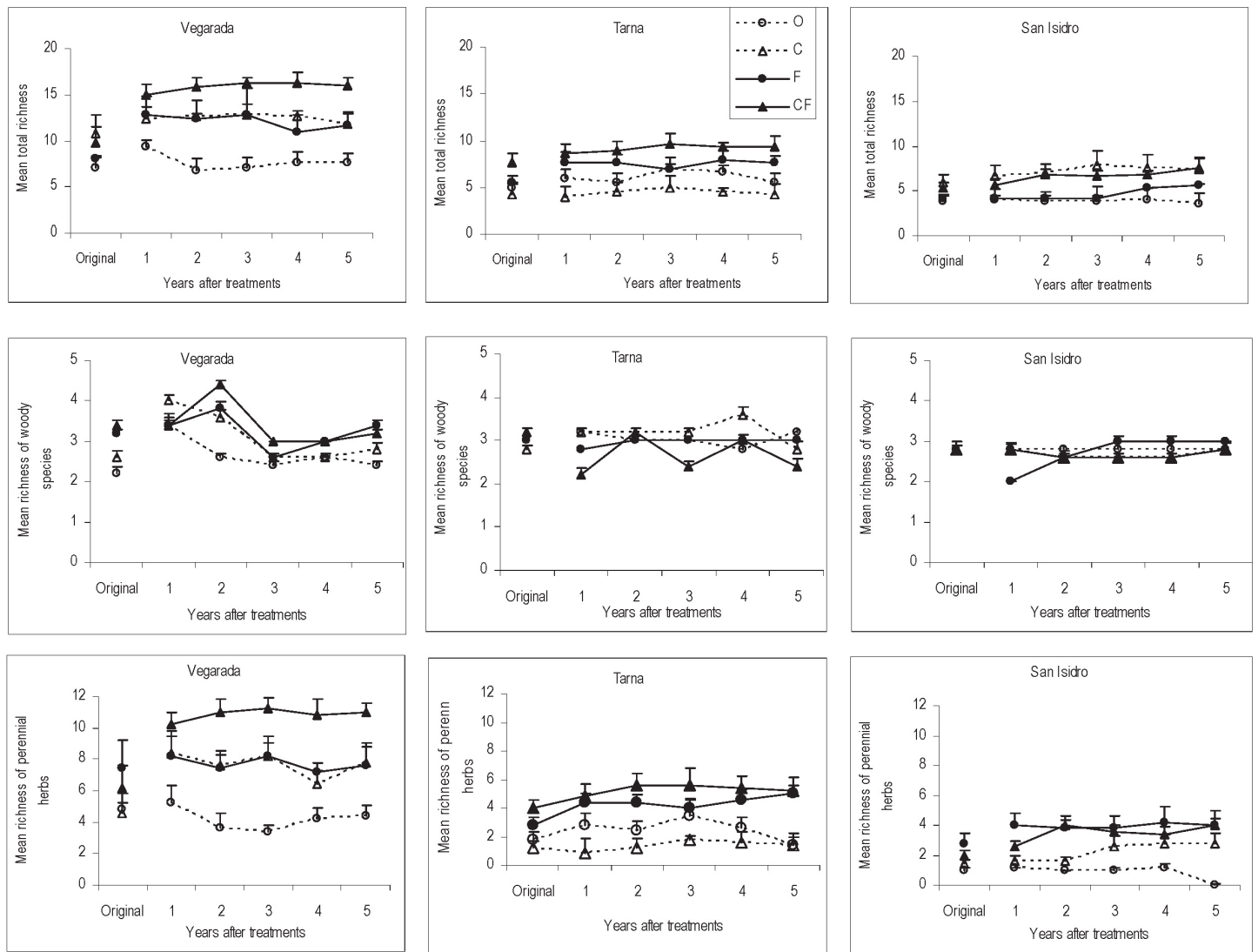

Fig. 1. Mean total richness, mean richness of woody species, mean richness of perennial herbs and standard error for three study areas (Vegarada, Tarna and San Isidro) in the original situation and 1, 2, 3, 4 and 5 years after treatments. $\mathrm{O}=$ control without fertilization, $\mathrm{F}=$ Fertilization, $\mathrm{C}=$ Calluna and Erica-cutting without fertilization, $\mathrm{CF}=$ Calluna and Erica-cutting plus fertilization. 
Table 1. Mean cover values (SD) of the most important species in Vegarada, in the original situation and five years after treatments. $\mathrm{O}=$ control without fertilization, $\mathrm{F}=$ Fertilization, $\mathrm{C}=$ Calluna and Erica-cutting without fertilization, $\mathrm{CF}=$ Calluna and Erica-cutting plus fertilization. Life forms: $\mathrm{AG}=$ Annual graminoids herbs, $\mathrm{AF}=$ Annual forbs, $\mathrm{PG}=\mathrm{Perennial}$ graminoids, $\mathrm{PF}=$ Perennial forbs, $\mathrm{W}=$ Woody species.

\begin{tabular}{|c|c|c|c|c|c|c|c|c|c|}
\hline & $\begin{array}{l}\text { Life } \\
\text { form }\end{array}$ & $\begin{array}{c}\mathrm{O} \\
\text { Original }\end{array}$ & $\begin{array}{c}\mathrm{O} \\
5 \text { years }\end{array}$ & $\begin{array}{c}\mathrm{F} \\
\text { Original }\end{array}$ & $\begin{array}{c}\mathrm{F} \\
5 \text { years }\end{array}$ & $\begin{array}{c}\mathrm{C} \\
\text { Original }\end{array}$ & $\begin{array}{c}\mathrm{C} \\
5 \text { years }\end{array}$ & $\begin{array}{c}\mathrm{CF} \\
\text { Original }\end{array}$ & $\begin{array}{c}\mathrm{CF} \\
5 \text { years }\end{array}$ \\
\hline Aira caryophyllea & $\mathrm{AG}$ & & & & & & $1.6(2.3)$ & & $4.0(1.8)$ \\
\hline Jasione montana & $\mathrm{AF}$ & $0.4(0.5)$ & & $0.8(0.4)$ & $2.0(2.7)$ & $1.0(2.2)$ & $2.6(4.3)$ & $0.2(0.4)$ & $0.6(1.3)$ \\
\hline Melampyrum pratense & $\mathrm{AF}$ & & $3.4(4.2)$ & & $2.2(2.1)$ & & & & $0.8(1.3)$ \\
\hline Agrostis capillaris & PG & & $1.4(2.19)$ & & $6.2(6.3)$ & & $7.0(5.7)$ & & $4.0(4.8)$ \\
\hline Anthoxanthum odoratum & PG & & & & $1.0(2.2)$ & & $5.6(6.6)$ & & $1.6(1.9)$ \\
\hline Carex muricata & PG & $0.6(0.4)$ & $1.6(2.3)$ & $1.2(2.2)$ & $2.8(2.2)$ & $6.0(6.5)$ & $3.0(2.7)$ & $2.2(4.2)$ & $3.6(3.7)$ \\
\hline Carex nigra & PG & & $1.6(2.3)$ & $0.6(1.3)$ & & $3.8(6.3)$ & $2.0(4.4)$ & $1.0(2.2)$ & $7.0(6.4)$ \\
\hline Danthonia decumbens & PG & & $0.6(1.3)$ & & $1.0(2.2)$ & $1.0(2.2)$ & $1.0(2.2)$ & $0.6(1.3)$ & $5.0(5.0)$ \\
\hline Deschampsia flexuosa & PG & & $0.4(0.8)$ & & $0.6(0.9)$ & & & & $4.0(4.8)$ \\
\hline Festuca rubra & PG & $1.2(2.2)$ & & $7.0(4.5)$ & $2.0(4.5)$ & $1.0(2.2)$ & $4.4(6.1)$ & $7.0(8.3)$ & $3.0(2.6)$ \\
\hline Juncus squarrosus & PG & & & & & & & & $3.0(3.6)$ \\
\hline Luzula sp & PG & & $0.2(0.4)$ & & $1.2(1.6)$ & $2.8(1.7)$ & $3.0(2.7)$ & $2.0(2.7)$ & $5.0(6)$ \\
\hline Nardus stricta & PG & $8.0(11.5)$ & $1.0(2.2)$ & $10.0(9.3)$ & $7.0(8.3)$ & $7.0(1.09)$ & $12.0(11.5)$ & $3.0(4.5)$ & $19.0(20.8)$ \\
\hline Arenaria montana & $\mathrm{PF}$ & $3.0(6.7)$ & & & & $0.8(1.3)$ & & & \\
\hline Conopodium majus & $\mathrm{PF}$ & $2.4(4.9)$ & $0.8(1.3)$ & & $0.2(0.4)$ & $1.2(1.6)$ & & $0.4(0.8)$ & $0.4(0.08)$ \\
\hline Dactylorhiza maculata & $\mathrm{PF}$ & $1.6(2.3)$ & & $0.4(0.5)$ & & $1.4(2.1)$ & & $0.6(1.3)$ & \\
\hline Galium saxatile & $\mathrm{PF}$ & $0.2(0.4)$ & $0.2(0.4)$ & & $0.2(0.4)$ & $1.0(2.2)$ & $1.4(2.1)$ & $0.4(0.5)$ & $8.0(3.6)$ \\
\hline Gentiana pneumonanthe & $\mathrm{PF}$ & & & & $0.2(0.4)$ & & & & $0.4(0.4)$ \\
\hline Hieracium pilosella & $\mathrm{PF}$ & $0.2(0.4)$ & $0.2(0.4)$ & $2.8(4.2)$ & $4.0(4.18)$ & $3.2(4.3)$ & $6.0(6.5)$ & $2.6(4.2)$ & $8.0(6.6)$ \\
\hline Muscari comosum & $\mathrm{PF}$ & $0.6(1.3)$ & & $2.6(3.7)$ & & $2.8(2.3)$ & & $2.6(2.5)$ & \\
\hline Narcisus pseudonarcisus & $\mathrm{PF}$ & $0.4(0.5)$ & $1.0(1.0)$ & & $2.6(2.3)$ & $0.6(0.9)$ & $0.6(0.9)$ & $0.8(1.3)$ & $1.4(1.3)$ \\
\hline Plantago serpentina & $\mathrm{PF}$ & $0.2(0.4)$ & & $0.2(0.4)$ & & & $2.0(4.5)$ & & $0.2(0.2)$ \\
\hline Polygala serpyllifolia & $\mathrm{PF}$ & & $0.6(1.3)$ & & $0.4(0.9)$ & & $0.8(1.3)$ & & $0.6(1.3)$ \\
\hline Potentilla erecta & $\mathrm{PF}$ & $3.2(3.4)$ & $5.8(6.4)$ & $3.2(2.0)$ & $10.4(5.3)$ & $4.6(3.2)$ & $15.0(12.7)$ & $2.4(1.9)$ & $22.0(24.4)$ \\
\hline Scilla verna & $\mathrm{PF}$ & & & & & & $0.2(0.4)$ & & \\
\hline Veronica officinalis & $\mathrm{PF}$ & & & & & & & & $0.8(0.8)$ \\
\hline Calluna vulgaris & W & $77.0(10.9)$ & $76.0(12.9)$ & $63.0(23.3)$ & $71.0(17.5)$ & $55.0(32.7)$ & $10.0(6.12)$ & $58.0(23.0)$ & $7.0(2.7)$ \\
\hline Erica tetralix & $\mathrm{W}$ & $7.0(13.1)$ & $3.0(6.71)$ & $5.0(8.7)$ & $9.2(17.3)$ & $26.0(15.1)$ & $33.0(26.3)$ & $25.0(16.9)$ & $31.0(26.1)$ \\
\hline Vaccinium myrtillus & $\mathrm{W}$ & $17.0(18.2)$ & $26.0(13.4)$ & $11.0(11.9)$ & $23.0(6.7)$ & $17.6(8.4)$ & $28.0(18.2)$ & $18.0(4.5)$ & $19.0(11.9)$ \\
\hline
\end{tabular}

$(F=9.32, P<0.05)$, Tarna $(F=3.20, P<0.05)$ and San Isidro $(F=4.61, P<0.01)$.

\section{Life form cover}

The cover values of the woody species $(F=2.6, P$ $>0.05)$, annual forbs $(F=0.69 ; P>0.05)$, perennial graminoids $(F=2.38 ; P>0.05)$ and perennial forbs $(F$ $=2.44 ; P>0.05$ ) had not significantly increased five years after fertilization in relation to the original situation in the three study areas (Tables 1, 2, 3). However, only Tarna showed a significant increase in perennial forbs cover $(F=5.92, P<0.05)$ after fertilization when control plots $(\mathrm{O})$ were compared with fertilized plots (F). In terms of cover, the perennial graminoid species benefiting most from fertilization were Agrostis capillaris and Carex muricata in Vegarada (Table 1); Eleocharis palustris and Juncus squarrosus in Tarna (Table 2) and Nardus stricta in San Isidro (Table 3). The perennial forbs most favoured by fertilization in the three study areas were Potentilla erecta and Hieracium pilosella only in Vegarada (Tables 1, 2, 3).

Therefore, it could be stated that, in general, the increase of nitrogen availability over time in the Cantab- rian heathlands allowed flora richness to increase. This is mainly due to the increased richness of the perennial herb species, since the woody and annual species were not affected. Fertilization did not have significant effects on the cover values of different life forms.

\section{Effect of cutting}

\section{Richness}

The cutting treatment $(\mathrm{C})$ meant that the community started to recover via the process of secondary succession. Total richness was constant after cutting over the study period and did not differ significantly from the original situation in any of the study areas (Fig. 1). It indicated a significant increase $(F=10.88, P<0.05)$ in perennial graminoid richness after cutting in all the study areas (Tables 1 - 3).

\section{Life form cover}

Woody cover values had not recovered five years after cutting in San Isidro $(F=41.24 ; P<0.05)$ and Tarna $(F=20.6, P<0.01)$, showing significant differences in relation to the original situation. However, at 
Table 2. Mean cover values (s.d.) of the most representative species in Tarna, in the original situation and five years after treatments. $\mathrm{O}=$ control without fertilization, $\mathrm{F}=$ Fertilization, $\mathrm{C}=$ Calluna and Erica-cutting without fertilization, $\mathrm{CF}=$ Calluna and Erica-cutting plus fertilization. Life forms as in Table 1.

\begin{tabular}{|c|c|c|c|c|c|c|c|c|c|}
\hline & $\begin{array}{l}\text { Life } \\
\text { forms }\end{array}$ & $\begin{array}{c}\mathrm{O} \\
\text { Original }\end{array}$ & $\begin{array}{c}\mathrm{O} \\
5 \text { years }\end{array}$ & $\begin{array}{c}\mathrm{F} \\
\text { Original }\end{array}$ & $\begin{array}{c}\mathrm{F} \\
5 \text { years }\end{array}$ & $\begin{array}{c}\mathrm{C} \\
\text { Original }\end{array}$ & $\begin{array}{c}\mathrm{C} \\
5 \text { years }\end{array}$ & $\begin{array}{c}\mathrm{CF} \\
\text { Original }\end{array}$ & $\begin{array}{c}\mathrm{CF} \\
5 \text { years }\end{array}$ \\
\hline Jasione montana & $\mathrm{AF}$ & & & & & & & $0.2(0.4)$ & $1.0(2.2)$ \\
\hline Melampyrum pratense & $\mathrm{AF}$ & $0.4(0.9)$ & $1.4(2.2)$ & & $0.6(1.3)$ & & $0.2(0.5)$ & $0.4(0.9)$ & $0.2(0.4)$ \\
\hline Agrostis capillaris & PG & & & & & & & & $0.6(1.3)$ \\
\hline Carex nigra & PG & $2(4.5)$ & & & & & & $1.2(2.2)$ & $2(4.4)$ \\
\hline Eleocharis palustris & PG & & $2.2(2.6)$ & & $10(9.3)$ & & $4.2(6.4)$ & & $3(6.7)$ \\
\hline Festuca rubra & PG & & & & & & & & $4.6(3.6)$ \\
\hline Juncus squarrosus & PG & & $2.6(4.3)$ & & $6(8.2)$ & & $3(6.7)$ & & $12(16.8)$ \\
\hline Nardus stricta & PG & & & $3(4.4)$ & & & & $9(10.8)$ & $6(13.4)$ \\
\hline Scirpus caespitosus & PG & $2.4(4.2)$ & & $6(6.5)$ & & $2.4(2.5)$ & & $0.6(1.3)$ & \\
\hline Doronicum carpetanum & $\mathrm{PF}$ & & & & $0.6(1.3)$ & & & & $1(2.2)$ \\
\hline Galium saxatile & $\mathrm{PF}$ & & & & & & & & $1(2.2)$ \\
\hline Homogyne alpina & $\mathrm{PF}$ & & & $0.4(0.8)$ & $3.0(4.7)$ & & & & $2(4.7)$ \\
\hline Narcisus pseudonarcissus & $\mathrm{PF}$ & & & & $3.4(4.1)$ & & & & $1.2(1.1)$ \\
\hline Potentilla erecta & $\mathrm{PF}$ & $1.8(2.0)$ & $2.6(4.3)$ & $3.4(4.2)$ & $10(12.3)$ & $0.6(1.3)$ & $2.0(4.5)$ & $2.4(1.6)$ & $11(4.1)$ \\
\hline Scilla verna & $\mathrm{PF}$ & $0.6(1.3)$ & $0.2(0.4)$ & $8(5.7))$ & & $0.2(0.4)$ & & $6.4(7.9)$ & \\
\hline Calluna vulgaris & W & $72(15.2)$ & $76(15.2)$ & $79(8.9)$ & $69(19.5)$ & $62(14.8)$ & $17(5.7)$ & $58(17.5)$ & $16(9.6)$ \\
\hline Erica tetralix & $\mathrm{W}$ & $17.4(11.3)$ & $22.2(14.9)$ & $16.4(12.3)$ & $14(5.4)$ & $33(20.8)$ & $29(11.4)$ & $22(17.5)$ & $16(17.8)$ \\
\hline Vaccinium myrtillus & $\mathrm{W}$ & $11.2(9.3)$ & 19 (12.94) & $11(6.5)$ & $15(15)$ & $20(16.2)$ & $10(3.5)$ & $21(11.9)$ & $5(8.6)$ \\
\hline
\end{tabular}

Vegarada there were no significant differences relative to the original situation. The dominant woody species, Calluna vulgaris, had the poorest regeneration (Tables 1 - 3). However, species which have a great capacity for resprouting or germination, as in the case of Erica tetralix and Vaccinium myrtillus, showed higher cover values five years after cutting than in the original situation.

Perennial graminoids cover only increased at San Isidro five years after cutting, due mainly to the high cover values of Festuca rubra (Table 3). The appearance of the following annuals was noted at Vegarada five years after cutting, all with low cover values: annual forbs Melampyrum pratense and Jasione montana; annual graminoids Aira caryophyllea (Tables 1 - 3).

When cover values of life forms from the cut plot (C) and the control plots $(\mathrm{O})$ were compared, a significant increase in perennial graminoids was only evident at Vegarada $(F=8.62, P<0.05)$. The remaining life forms showed no significant differences between cut and control plots.

Table 3. Mean cover values (SD) of the most representative species in San Isidro, in the original situation and five years after treatments. $\mathrm{O}=$ control without fertilization, $\mathrm{F}=$ Fertilization, $\mathrm{C}=$ Calluna and Erica-cutting without fertilization, $\mathrm{CF}=$ Calluna and Erica-cutting plus fertilization. Life forms as Table 1.

\begin{tabular}{|c|c|c|c|c|c|c|c|c|c|}
\hline & $\begin{array}{l}\text { Life } \\
\text { form }\end{array}$ & $\begin{array}{c}\mathrm{O} \\
\text { Original }\end{array}$ & $\begin{array}{c}\mathrm{O} \\
5 \text { years }\end{array}$ & $\begin{array}{c}\mathrm{F} \\
\text { Original }\end{array}$ & $\begin{array}{c}\mathrm{F} \\
5 \text { years }\end{array}$ & $\begin{array}{c}\mathrm{C} \\
\text { Original }\end{array}$ & $\begin{array}{c}\mathrm{C} \\
5 \text { years }\end{array}$ & $\begin{array}{c}\mathrm{CF} \\
\text { Original }\end{array}$ & $\begin{array}{c}\mathrm{CF} \\
5 \text { years }\end{array}$ \\
\hline Aira caryophyllea & $\mathrm{AG}$ & & & & & $0.4(0.6)$ & $0.6(1.3)$ & $0.2(0.4)$ & $1.4(2.1)$ \\
\hline Jasione montana & $\mathrm{AF}$ & & & & & & $2.0(4.5)$ & $0.4(0.5)$ & $0.2(0.4)$ \\
\hline Agrostis capillaris & PG & & & & & & $3.6(4.2)$ & & $2.0(4.5)$ \\
\hline Carex muricata & PG & & & $1.2(2.2)$ & $1.0(2.2)$ & & $0.6(1.3)$ & & $0.6(0.9)$ \\
\hline Deschampsia flexuosa & PG & $0.6(0.9)$ & & $1.6(1.9)$ & & $4.0(2.2)$ & $0.6(1.3)$ & $7.2(7.1)$ & $3.2(6.6)$ \\
\hline Festuca rubra & PG & & & & & & $14.0(20.4)$ & & $1.8(2.2)$ \\
\hline Juncus squarrosus & PG & & & $0.6(1.3)$ & & $0.6(1.3)$ & $1.0(2.2)$ & $1.2(1.3)$ & $5.4(6.7)$ \\
\hline Nardus stricta & PG & $3.0(4.5)$ & $2.6(1.8)$ & $0.6(1.3)$ & $5.2(4.5)$ & $2.6(1.6)$ & $9.0(5.5)$ & $4.0(6.5)$ & $26.2(16.3)$ \\
\hline Galium saxatile & $\mathrm{PF}$ & & & & & & $2.0(4.5)$ & & $2.2(4.4)$ \\
\hline Hieracium pilosella & $\mathrm{PF}$ & & & & & & $1.0(2.2)$ & & \\
\hline Narcisus pseudonarcissus & $\mathrm{PF}$ & & & & & & & & $0.2(0.4)$ \\
\hline Polygala serpyllifolia & $\mathrm{PF}$ & & & & & & & & $0.6(1.3)$ \\
\hline Potentilla erecta & $\mathrm{PF}$ & $0.2(0.4)$ & & & $1.0(2.2)$ & $0.6(0.8)$ & $4.0(4.2)$ & & $1.0(2.2)$ \\
\hline Rumex acetosella & $\mathrm{PF}$ & & & $0.2(0.4)$ & & $0.2(0.4)$ & & & \\
\hline Calluna vulgaris & $\mathrm{W}$ & $81.0(13.4)$ & $68.0(8.3)$ & $65.0(12.2)$ & $68.0(13.0)$ & $83.0(13.0)$ & $9.0(5.5)$ & $64.0(16.7)$ & $11.0(4.1)$ \\
\hline Erica tetralix & W & $20.0(3.5)$ & $36.0(12.9)$ & $30.6(27.5)$ & $33.0(29.1)$ & $12.6(8.1)$ & $19.0(12.4)$ & $13.0(5.7)$ & $18.0(13.0)$ \\
\hline Vaccinium myrtillus & W & $8.0(4.5)$ & $11.0(6.5)$ & $4.2(3.6)$ & $13.0(4.4)$ & $8.0(5.7)$ & $15.0(12.2)$ & $5.6(4.4)$ & $10.0(7.1)$ \\
\hline
\end{tabular}




\section{Effect of cutting plus fertilization}

\section{Richness}

The effect of cutting was compared with that of cutting plus fertilization by analysing the $\mathrm{C}$ and $\mathrm{CF}$ plots together. The areas with high richness values in the original situation, Vegarada $(F=6.09, P<0.01)$ and Tarna $(F=17.03, P<0.01)$, showed a significant increase in total richness (Fig. 1) after cutting plus fertilization. Similarly, in all the study areas there was a significant increase $(F=15.08, P<0.01)$ in total richness after five years compared with the original situation (Fig. 1, Tables 1 - 3). This increase in global richness was due mainly to the significant increase $(F=6.32 ; P<0.05)$ in richness of perennial herbs (Fig. 1). Annual graminoids and forbs (Tables 1 - 3) did not show a significant increase in richness values five years after cutting plus fertilization.

When cutting plus fertilization was compared with the control $(\mathrm{O})$, it was evident that total richness increased significantly $(F=14.69 ; P<0.01)$ in all the study areas (Fig. 1), even after five years. This increase was caused by the elimination of dominant species, allowing other annual and perennial herb species such as Conopodium majus, Galium saxatile, Polygala serpyllifolia, Narcissus pseudonarcissus and Veronica officinalis (Tables 1 - 3) opportunities to colonize the resulting gaps.

\section{Life form cover}

Woody cover values had not recovered five years after cutting plus fertilization, showing significant differences in all the study areas $(F=48.06, P<0.05)$ in relation to the original situation. Calluna vulgaris did not recover its original values, but Erica tetralix and Vaccinium myrtillus showed higher cover values than the original situation, particularly in Vegarada and San Isidro (Tables 1 - 3). Cover values for perennial graminoids species increased significantly after cutting plus fertilization in Vegarada $(F$ $=5.17, P<0.05)$, San Isidro $(F=12.73, P<0.05)$ and Tarna $(F=10.59, P<0.05)$ (Tables $1-3)$. The perennial graminoids which appeared either exclusively, or with comparatively, higher values in the cut plus fertilized plots were: Nardus stricta, Carex nigra, Juncus squarrosus and Agrostis capillaris (Tables 1 - 3). Cover values for perennial forbs did not show a clear pattern in the three study areas. There was a significant increase $(F=$ 15.07, $P<0.05)$ in the cover values of this life form at Vegarada. The perennial forb most favoured by cutting plus fertilization was Potentilla erecta (Tables 1 - 3). Cover values for annual graminoids and forbs were not affected by experimental treatments.

In general, a predominance of perennial graminoids and a significant increase in global richness were observed five years after cutting plus fertilization. These effects were more pronounced in the areas with greater richness in the original situation. After comparison of all the treatments, cutting plus fertilization showed a significant increase in total richness values.

\section{Multivariate analysis of treatments}

APCA of the mean cover and richness of the different life forms and mean cover of the two dominant woody species was carried out for each study area. The results obtained were similar in the three areas, so only the PCA for Tarna is presented (Fig. 2). Axis 1 (which explained $38 \%$ of total variance) discriminated fertilization ef-

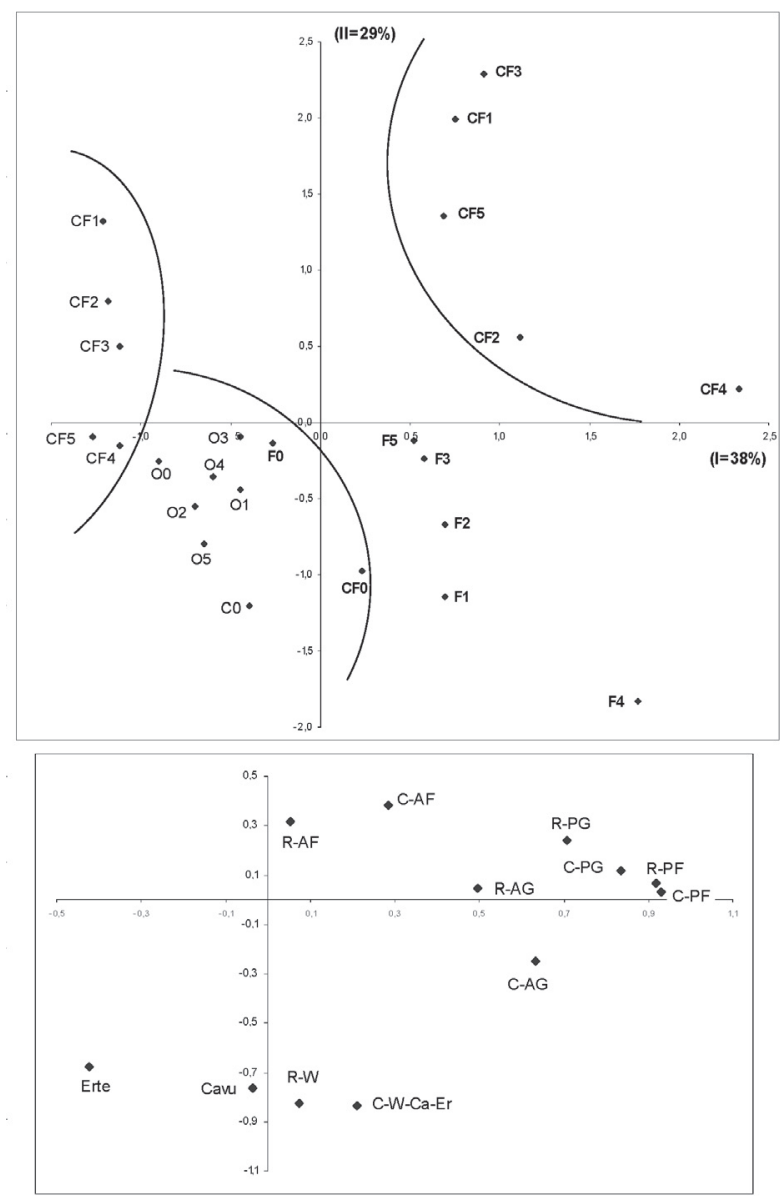

Fig. 2. Plot of the samples and variables used in the PCA in the plane defined by the two first axes in Tarna. Abbreviations: cover of Calluna vulgaris (Cavu), cover of Erica tetralix (Erte), cover of rest of woody species (W-Ca-Er), cover perennial forbs (C-PF), cover perennial graminoids (C-PG), cover annual forbs (C-AF) and cover annual graminoids (C-AG); Richness of woody species (R-W), richness of perennial forbs (R-PF), richness of perennial graminoids (R-PG), richness of annual forbs (R-AF) and richness of annual graminoids (R-AG). $\mathrm{O}=$ control without fertilization, $\mathrm{F}=$ Fertilization, $\mathrm{C}=$ Callun $a$ and Erica-cutting without fertilization, $\mathrm{CF}=$ Calluna and Ericacutting plus fertilization, $0=$ original situation; 1, 2, 3, 4 and 5 years after treatments. 
fects, which were associated on the positive axis with the highest cover and richness values of the perennial forbs and graminoids. Axis 2 (which explained 29\% of the total variance) differentiated the plots in which the woody species Calluna and Erica had been cut from the remaining plots. On the negative side, control plots $(\mathrm{O})$ and fertilized plots $(F)$ were grouped and were associated with high cover values and richness for woody species. Moreover, data from the original situation and control plots $(\mathrm{O})$ over time formed a group, which was associated with the highest cover values for Calluna and Erica. Finally, axis 2 allowed the identification of a temporal tendency towards regeneration in the $\mathrm{C}$ plots such that, four and five years after cutting, the samples were very similar to the original situation. However, this temporal tendency was not observed in the cutting plus fertilization plots $(\mathrm{CF})$ due to the greater presence of perennial herbs and poor recovery of woody species.

Effect of the increase in perennial herbs and perennial graminoids cover on the dominant species (Calluna vulgaris) after cutting and fertilization

After cutting, there was no evidence that increased cover of total perennial herbs and perennial graminoids had a significant negative effect on Calluna vulgaris cover in the three study areas (Fig. 3). On the contrary, there was a significant positive correlation between Calluna cover, perennial herbs $(r=0.65, P<0.05)$ and perennial graminoids $(r=0.62 ; P<0.05)$ over time in Tarna.

After cutting plus fertilization (CF), (Fig. 3) Vegarada showed a significant positive correlation in the cover of Calluna and perennial herbs $(r=0.65, P<0.05)$ and also with perennial graminoids $(r=0.56, P<0.05)$. However, San Isidro $(r=-0.22, P>0.05)$ and Tarna $(r=-0.23$, $P>0.05)$ did not show significant correlations between these variables.

Therefore, the increase in cover values of the perennial herbs and perennial graminoids after cutting or cutting plus fertilization had no negative effect on the recovery of the dominant species of these communities, Calluna vulgaris, in secondary succession processes.

\section{Discussion}

The species composition, species diversity and primary productivity of terrestrial ecosystems, including heathlands, are strongly affected by the rates at which limiting nutrients such as nitrogen are supplied (Wedin \& Tilman 1990; Wilson \& Tilman 1991; Olff et al. 1994; Berendse 1998).

Heathland field experiments have demonstrated positive growth responses of Calluna to nitrogen addition over varying time scales (Caporn et al. 1994; Pitcairn \& Fowler 1995; Power et al. 1998a, b; Carroll et al. 1999). Nitrogen addition also produces an increase in shoot growth, flowering and litter production (Iason \& Hester 1993; Lee \& Caporn 1998; Carroll et al. 1999; Baker et al. 2004). In experiments manipulating nitrogen deposition in the field, carried out on heathlands in the Cantabrian mountain range, fertilizer was seen not to produce significant effects on the growth response of Calluna (Calvo et al. 2005), demonstrating that even twice the rate of current atmospheric deposition is not enough to affect Calluna
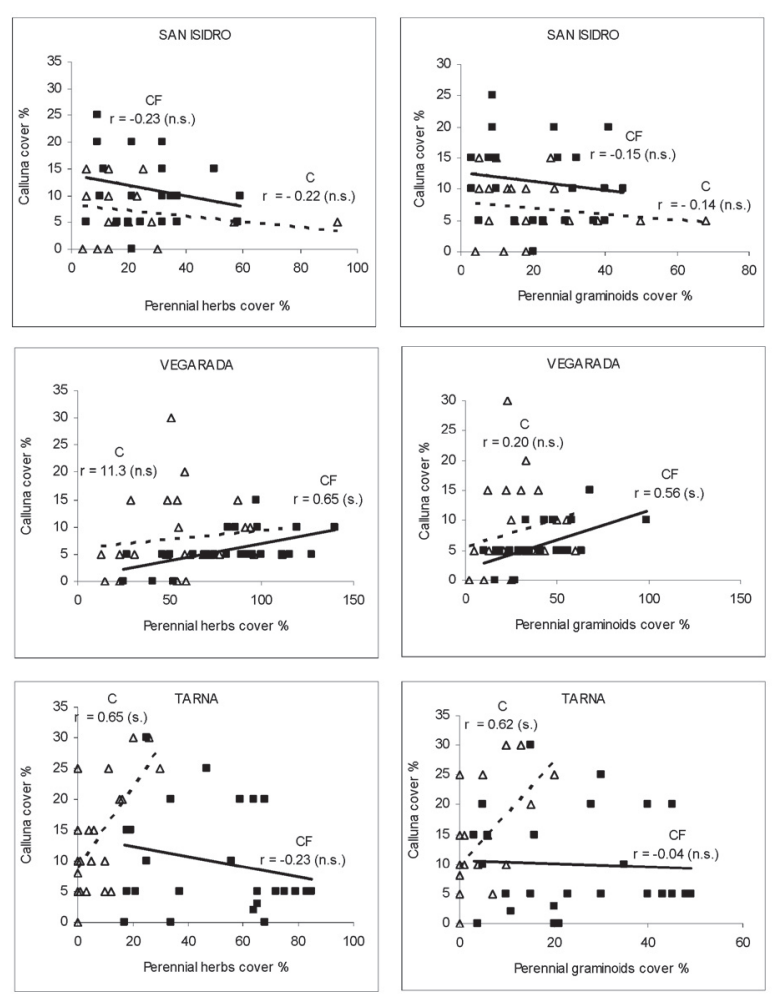

Fig. 3. Correlation between percentage cover of perennial herbs and graminoids and percentage cover of Calluna vulgaris in the three study areas after experimental treatments: $\mathrm{C}=$ Calluna and Erica-cutting without fertilization (discontinuous line and $\triangle$ ), $\mathrm{CF}=$ Calluna and Erica-cutting plus fertilization (continuous line and $\boldsymbol{\square}) . r=$ correlation coeficient. (s. = significant diferences; n.s. = no significant differences). 
growth in these mountain areas in the short term. However, after five years fertilization significant effects were observed in terms of increased richness in the studied heathlands. These increases were greater in the zones which had higher richness levels originally, Vegarada and Tarna, and lower in San Isidro, which originally had the poorest richness. This difference in vegetation richness is due to differences in the composition of the soil seed bank in the three zones (Valbuena et al. 2003). The addition of new species occurs from the seed bank in each zone and therefore those with greater seed bank richness (Vegarada and Tarna) (Valbuena et al. 2003) corresponded with the zones of greater field richness after fertilization. The significant increase in richness after nitrogen fertilization is primarily due to an increase in perennial herbaceous species. Herbaceous species have faster growth rates and respond more quickly to an increase in nutrients than slow growing shrubs (Heil \& Bruggink 1987). This increase in perennial herb richness after fertilization could be due to the increased availability of nitrogen in these nitrogen-poor heathlands (Marcos et al. 2003) which favoured higher germination levels of the number of seeds, mainly perennial herbs. Similar results of changes in the species composition of heathlands as a response to a rise in atmospheric nitrogen deposition have been documented in Dutch heathlands (Aerts 1993). An increase in the cover values of the perennial herb species is also recorded in the studied heathlands after fertilization, corresponding with work by Alonso \& Hartley (1998), who indicated that when heather is old, as in the present Cantabrian heathlands, fertilization may provide sufficient resources to allow grasses to spread successfully and rapidly.

Cutting is very common in southern parts of the western European heathland region. Calluna used to be cut to provide material for roof thatching, animal bedding and other purposes (Gimingham 1994). The regeneration of heathland species after cutting depends very much on the condition of the initial heather canopy, on the abundance and behaviour of herbivores, which select their diet in relation to nutrient content, on the persistence of the soil seed bank and on climatic conditions. Stem bases were undamaged and vegetative regeneration was effective in the current experiments. Grasses that had survived under a closed canopy of Calluna in the pre-cut vegetation spread rapidly in the plots, probably as the result of increased light availability. Studies carried out in the Cantabrian mountain range show that after removal of the woody canopy, grasses can become established, and those already present can increase in cover and eventually become very abundant, as is the case for Nardus stricta. However, the greatest increases in both richness and cover are always found when there is cutting plus fertilization. The perennial herb species
(Potentilla erecta, Nardus stricta and in some areas Juncus squarrosus) are mainly responsible for such marked changes. It is possible that the elimination of competition with woody species may have allowed the rapid expansion of herbaceous taxa, a process which may have been promoted by the increased availability of scarce nutrients such as nitrogen. The contribution to richness of annual herbs is minimal, as shown by other studies carried out in these areas (Calvo et al. 2002).

This increase in the cover values of perennial herb species during the first few years of recovery could pose a problem for the regeneration of the dominant woody species, as recorded in some studies carried out on heathlands in The Netherlands. These studies showed a strong relationship between the increase in nitrogen and the replacement of shrubs by herbaceous species (Berdowski \& Zeilinga 1987; Prins et al. 1991; Van der Eerden et al. 1991; Aerts 1993; Berdowski 1993; Bobbink \& Heil 1993; Berendse et al. 1994). However, many authors have shown that if the original shrub cover is not under stress (e.g. through overgrazing), woody species have competitive advantages over herbaceous species, such as Nardus stricta (Alonso \& Hartley 1998) or Molinia caerulea (Heil \& Bruggink 1987), in the longer term. In the field studies carried out in the Cantabrian mountain range, cover values for perennial herbs and graminoids had no negative effects on the cover of Calluna vulgaris after cutting and cutting plus fertilization throughout the five year study. That is, there was no displacement of Calluna vulgaris due to competition with the perennial herbs in the zone. Similar results have been recorded in field studies carried out in the UK (Power et al. 1998b, 2004; Carroll et al. 1999). These studies have reported that increased nitrogen deposition over periods of up to ten years stimulates Calluna growth, with little evidence of grass invasion. It seems clear that increased nutrient availability alone is probably not enough to trigger these changes (Heil \& Bruggink 1987; Prins et al. 1991; Heil \& Bobbink 1993). The role of the nutrients is very complex and changes in the species composition of a community will depend not only on an increase in nutrient availability, but also on the growth phase of the dominant species (Britton et al. 2003) and other factors, such as heather beetle Lochmaea suturalis and stress due to drought or frost (de Smidt 1977; Power et al. 1995).

It is generally accepted that localized disturbances create a patchy vegetation structure with regeneration niches which play a key role in maintaining species richness (van der Maarel 1996; Sedlákova \& Chytrý 1999). Therefore, if the scarce Cantabrian heathlands located in natural reserves are to be conserved, it is necessary to apply adapted management tools. The management of these ageing heathlands could be based on the cyclical creation of small patches where Calluna is cut and 
other older heathland patches are left intact. This would allow a mosaic of heathlands with patches of different ages. Cutting could be used as an alternative where it is not possible to carry out traditional patterns of grazing and burning, as this would allow maximum vegetation diversity to be maintained and, thus, the associated diversity of all the levels of organisms which use this vegetation.

\section{Conclusions}

In the studied heathlands, fertilization allowed vegetation biodiversity to increase over time within a medium time scale (five years). This increase was considerably greater after cutting plus fertilization than after cutting or after fertilization alone. The increase in global richness was fundamentally based on an increase in the number of perennial herbs. The rise in perennial herb richness also corresponded to an increase in cover values. Higher cover values for perennial herb species did not impede the recovery of the dominant species in these communities, Calluna vulgaris, during the secondary succession processes. Cutting patches of heathland is proposed as a mechanism for allowing high vegetation diversity and structure to be maintained.

Acknowledgements. The study was supported by the Diputación Provincial de León. F. Llamas (Department of Botany) helped with the taxonomy of the species. Thanks are due to L. Valbuena, A. López, R. Tárrega, R. Maze and all the enthusiasts who helped with the fieldwork during these years.

\section{References}

Anon. 1992. Council Directive of 21 May 1992 on the Conservation of Natural Habitats and of Wild Fauna and Flora (92/43/EEC). European Commission, Brussels, BE.

Aerts, R. 1993. Competition between dominant plant species in heathlands. In: Aerts, R. \& Heil, G.W. (eds.) Heathlands: Patterns and processes in a changing environment, pp. 51-84. Kluwer, Dordrecht, NL.

Alonso, I. \& Hartley, S.E. 1998. Effects of nutrient supply, light availability and herbivory on the growth of heather and three competing grass species. Plant Ecol. 137: 203-212.

Baker, C.G., Power, S.A., Bell, J.N.B. \& Orme, C.D.L. 2004. Effects of habitat management on heathland response to atmospheric nitrogen deposition. Biol. Conserv. 120: 41-52.

Berendse, F. 1998. Effects of dominant plant species on soils during succession in nutrient-poor ecosystems. Biogeochemistry 42: 73-88.

Berendse, F., Schmitz, M. \& De Visser, W. 1994. Experimen- tal manipulation of succession in heathland ecosystems. Oecologia 100: 38-44.

Berdowski, J.J.M. 1993. The effects of external stress and disturbance factors on Calluna-dominated heathland vegetation. In: Aerst, R.H. \& Heil, G.W. (eds.) Heathlands: Patterns and processes in a changing environment, pp. 85-124. Kluwer, Dordrecht, NL.

Berdowski, J.J.M. \& Zeilinga, R. 1987. Transition from heathland to grassland, damaging effects of the heather beetle. J. Ecol. 75: 159-175.

Berdowski, J.J.M. \& Siepel, H. 1988. Vegetative regeneration of Calluna vulgaris at different ages and fertilizer levels. Biol. Conserv. 46: 85-93.

Bobbink, R. 1991. Effects of nutrient enrichment in Dutch chalk grassland. J. Appl. Ecol. 28: 28-41.

Bobbink, R. \& Heil, G.W. 1993. Atmospheric deposition of sulphur and nitrogen in heathland ecosystems. In: Aerts, R.H. \& Heil, G.W. (eds.) Heathlands: Patterns and processes in a changing environment, pp. 25-50. Kluwer, Dordrecht, NL.

Britton, A.J., Pakeman R.J., Carey, P.D. \& Marrs, R.H. 2001. Impacts of climate, management and nitrogen deposition on the dynamics of lowland heathland. J. Veg. Sci. 12: 797-806.

Britton, A.J., Pakeman, R.J., Carey, P.D. \& Marrs, R.H. 2003. The influence of soil type, drought and nitrogen on interactions between Calluna vulgaris and Deschampsia flexuosa during heathland regeneration. Plant Ecol. 166: 93-105.

Calvo, L., Tárrega, R. \& Luis, E. 2002. Regeneration patterns in a Calluna vulgaris heathland in the Cantabrian mountains (NW Spain): effects of burning, cutting and ploughing. Acta Oecol. 23: 81-90

Calvo, L., Alonso, I., Fernández, A. J. \& Luis-Calabuig, E. 2005. Short term study of effects of fertilization and cutting treatments on the vegetation dynamics of mountain heathlands in Spain. Plant Ecol. 179: 181-191.

Caporn, S.J.M., Risager, M. \& Lee, J.A. 1994. Effect of nitrogen supply on frost hardiness in Calluna vulgaris (L.) Hull. New Phytol. 128: 461-468.

Carroll, J.A., Caporn, J.M., Cawley, L., Read, D.J. \& Lee, J.A. 1999. The effect of increased deposition of atmospheric nitrogen on Calluna vulgaris in upland Britain. New Phytol. 141: 423-431.

de Smidt, J.T. 1977. Interaction of Calluna vulgaris and the heather beetle (Lochmaea suturalis). In: R. Tüxen (ed.) Vegetation und Fauna, pp. 179-186. Cramer, Vaduz, LI.

Gimingham, C.H. 1994. Lowland heaths of West Europe: Management for conservation. Phytocoenologia 24: 615-626.

Hanson, M. \& Fogelfors, H. 2000. Management of a seminatural grassland: results from a 15-year-old experiment on southern Sweden. J. Veg. Sci. 11: 31-38.

Heil, G.W. \& Bobbink, R. 1993. Impact of atmospheric nitrogen deposition on dry heathlands. A stochastic model simulating competition between Calluna vulgaris and two grass species. In: Aerts, R.H. \& Heil, G.W. (eds.) Heathlands: Patterns and processes in a changing environment, pp. 181-200. Kluwer, Dordrecht, NL.

Heil, G.W. \& Bruggink, M. 1987. Competition between Calluna vulgaris (L.) Hull and Molinia caerulea (L.) Moench. 
Oecologia 73: 105-108.

Heil, G.W. \& Diemont, W.H. 1983. Raised nutrient levels change heathland into grassland. Vegetatio 53: 113-120.

Iason, G.R. \& Hester, A.J. 1993. The response of heather (Calluna vulgaris) to shade and nutrients predictions of the carbon-nutrient balance hypothesis. J. Ecol. 81: 75-80.

Lee, J.A. \& Caporn, S.J.M. 1998. Ecological effects of atmospheric reactive nitrogen deposition on semi-natural terrestrial ecosystems. New Phytol. 139: 127-134.

Marcos, E., Calvo, L. \& Luis-Calabuig, E. 2003. Effects of fertilization and cutting treatments on the chemical composition of the vegetation and soils of mountain heathlands in Spain. J. Veg. Sci. 14: 417-424.

Marrs, R.H. 1993. An assessment of change in Calluna heathlands in Breckland, Eastern England, between 1983 and 1991. Biol. Conserv. 65: 133-139.

Mohamed, B.F \& Gimingham, C.H. 1970. The morphology of vegetative regeneration in Calluna vulgaris. New Phytol. 69: 743-750.

Olff, H., Berendse, F. \& de Visser, W. 1994. Changes in N mineralization, tissue nutrient concentrations and biomass compartmentation after cessation of fertilizer application to mown grassland. J. Ecol. 82: 611-620.

Pitcairn, C.E.R. \& Fowler, D. 1995. Deposition of fixed atmospheric nitrogen and foliar nitrogen content of bryophytes and Calluna vulgaris (L.) Hull. Environ. Pollut. 88: 193-205.

Power, S.A., Ling, K.A. \& Ashmore, M.R. 1995. Recent trends in beech tree health in southern Britain and the influence of soil type. Water Air Soil Pollut. 85: 1293-1298.

Power, S.A., Ashmore, M.R., Cousins, D.A. \& Sheppard, L. J. 1998a. Effects of nitrogen addition on the stress sensitivity of Calluna vulgaris. New Phytol. 13: 663-673.

Power, S.A., Ashmore, M.R. \& Cousins, D.A. 1998b. Impacts and fate of experimentally enhanced nitrogen deposition on a British lowland heath. Environ. Pollut. 102: 27-34.

Power, S.A., Ashmore, M.R., Terry, A.C., Caporn, S.J.M., Pilkington, M.G., Wilson, D.B., Barker, C.G., Carroll, J.A., Cresswell, N., Green, E.R. \& Heil, G.W. 2004. Linking field experiments to long-term simulation of impacts of nitrogen deposition on heathlands and moorlands. Water Air Soil Poll. 4: 259-267.

Press, M.C., Woodin, S.J. \& Lee, J.A. 1986. The potential importance of an increased atmospheric nitrogen supply to the growth of ambrotrophic Sphagnum species. New Phytol. 103: 45-55.

Prins, A.H., Berdowski, J.J.M. \& Latuhihin, M.J. 1991. Effect of $\mathrm{NH}_{4}$-fertilization on the maintenance of a Calluna vulgaris vegetation. Acta Bot. Neerl. 40: 269-279.

Rose, R.J., Webb, N.R. Clarke, R.T. \& Traynor, C.H. 2000. Changes on the heathlands in Dorset, England, between 1987 \& 1996. Biol. Conserv. 93: 117-125.

Rivas-Martínez, S., Gandullo, J.M., Allue, J.L., Montero, J.L. \& González, J.L. 1987. Memoria del mapa de series de vegetación de España. ICONA, Madrid, ES.

Rivero Fernández, C., Rabago Juan-Aracil, I., Sousa Carrera, M., Lorente Ibáñez, M. \& Schmid, T. 1996. Cálculo y cartografía de cargas críticas para España. Aplicación del modelo SMB. CIEMAT, Madrid, ES.
Sedlákova, I. \& Chytrý, M. 1999. Regeneration patterns in a Central European dry heathland: effects of burning, sodcutting and cutting. Plant Ecol. 143: 77-87.

Tutin, T.G., Heywood, V.H., Burges, D.H., Valentine, D.H., Moore, D.M., Walters, S.M. \& Webb, D.A. (1964-1980). Flora Europaea. Cambridge University Press, Cambridge, UK.

Valbuena, L., Calvo, L., López, A., Tárrega, R. \& Luis, E. 2003. Estudio del banco de semillas del suelo en tres comunidades brezal dominadas por Calluna vulgaris. Procc. of VII Congreso Nacional de la Asociación Española de Ecología Terrestre. Barcelona, ES.

van der Maarel, E. 1996. Pattern and process in the plant community: fifty years after A.S. Watt. J. Veg. Sci. 7: 19-28.

van der Eerden, L.J., Dueck, Th.A., Berdowski, J.J.M., Greven, H. \& van Dobben, H.F. 1991. Influence of $\mathrm{NH}_{3}$ and $\left(\mathrm{NH}_{4}\right)_{2} \mathrm{SO}_{4}$ on heathland vegetation. Acta Bot. Neerl. 40: 281-296.

Watt, A.S. 1955. Bracken versus heather, a study in plant sociology. J. Ecol. 43: 490-506

Webb, N.R. 1998. The traditional management of European heathlands. J. Appl. Ecol. 35: 987-990.

Wedin, D.A. \& Tilman, D. 1990. Species effects on nitrogen cycling: a test with perennial grasses. Oecologia 84: 433-441.

Wilson, S.D. \& Tilman, D. 1991. Interactive effects of fertilization and disturbance on community structure and resource availability in an old-field plant community. Oecologia 88: 61-71.
Received 24 August 2005;

Accepted 2 February 2006; Co-ordinating Editor: R. Pakeman. 